\title{
Breeding success of a colony of Boat-billed Herons Cochlearius cochlearius (Ciconiiformes: Ardeidae) in pasturelands of Costa Rica
}

\author{
Jaime Gómez, José A. Gil-Delgado \& Juan S. Monrós \\ Instituto "Cavanilles" de Biodiversidad y Biología Evolutiva, Universidad de Valencia, Apdo. Oficial 2085, E-46071 \\ Valencia, Spain; Jaime.Gomez@uv.es; gild@uv.es; monros@uv.es \\ Received 16-V-2003. Corrected 04-XI-2005. Accepted 02-VI-2006.
}

\begin{abstract}
The breeding success of a double-brooding colony of Boat-billed Herons Cochlearius cochlearius was studied in pasturelands of Costa Rica. Mean clutch size in the first clutches (2.9 eggs/nest) was higher than in second and repeat clutches (2.3 eggs/nest). Breeding success was similar in the first attempt and second attempts $(20.7 \%$ and $21.7 \%$, respectively). In both attempts earlier nests enjoyed a higher breeding success. Starvation of the youngest chicks within the nest and destruction of nests by bad weather conditions were the main factors related to nestling death. No effects of human activity on the reproduction of the breeding colony were observed. Rev. Biol. Trop. 54 (4): 1131-1134. Epub 2006 Dec. 15.
\end{abstract}

Key words: boat-billed Heron, Cochlearius cochlearius, human activity, clutch size, predation, starvation.

The Boat-billed Heron Cochlearius cochlearius (Linnaeus, 1766) inhabits the wooded or mangrove fringes of freshwater creeks, lakes and marshlands from Mexico south to Peru, Bolivia and northeastern Argentina (Hancock and Kushlan 1984).

This species breeds solitarily or in colonies (Carbonell 1993), and two peaks of activity have been observed during the nesting season of some colonies (Dickerman and Juárez 1971, Carbonell 1993). Similar results were recorded by Gómez et al. (2001), who assessed the second peak of activity to the occurrence of second and repeat clutches.

Previous studies of some Boat-billed colonies pointed out that human presence appeared to affect breeding success. In fact, Juarez (1967) reported the occurrence of nest desertion and predation when humans came close to the colony and also reported on the effects of mangrove pruning and egg robbery on the breeding success of these herons. Further, Wetmore (1965) pointed out that this species disappears from areas occupied by humans.
The capacity of a species to tolerate the effects of habitat transformation can be an important factor to consider in their conservation. Information on the status of the populations in transformed areas and the factors related to their survival can help us to determine conservation guidelines.

This paper presents some data on the breeding of a colony of Boat-billed Herons in pasturelands of Costa Rica and compares the breeding success of the first and second attempts. We do a comparison of the results of other studies that have been done and discuss whether or not human presence is compatible with the conservation of this species.

\section{MATERIALS AND METHODS}

The study was conducted in Santa Clara de San Carlos (Province of Alajuela, $10^{\circ} 21^{\prime} \mathrm{N}$, $84^{\circ} 30^{\prime} \mathrm{W}, 150$ masl) located on the northern Caribbean Slope of Costa Rica. In this area pastures prevail, since stockbreeding is the 
major economic activity, although agriculture plots and human settlements are also present. Scattered along the many rivers and creeks are patches of forest.

During almost two years, the studied colony was observed in the surroundings of a small lagoon in the village of Santa Clara. A narrow strip of forest along the border of the lagoon was the colony of Boat-billed Herons, where they normally roosted and foraged, but it was also the site of a chicken farm and the owner's house. As a result, there was continuous human activity meters away from the bird colony.

Villagers informed us that the colony had bred in this area for some years, using in 1998 and 1999 two mango trees (Mangifera indica) next to the chicken farm at the edge of the lagoon for nesting.

The present study covers the breeding season of 1999. A sketch of the trees with the location of each nest was mapped out to facilitate the identification and monitoring of the nests on visits every one to four days. The content of each nest was recorded by climbing up the trees. Visits were avoided on rainy days and females were not disturbed if they remained on their nest during inspection to prevent damage. For some nests, the exact date of the laying of the first egg was known. For the rest, the date the first egg was laid was calculated by backdating, assuming 28 days (Juarez 1967, Gómez et al. 2001) for laying and incubation.

Thirty nests were found from February to July and were distributed in two marked periods of laying, with 15 nests in each period. Nests in the first period were in use mostly during the dry season; second period clutches started at the beginning of the rainy season and developed when precipitation was high. The absence of other individuals in the area, as well as the concordance between the maximum number of adults counted (30 individuals) and the 14 nests with eggs simultaneously in each period, revealed the occurrence of second clutches and repeat attempts (Gómez et al. 2001).

The survival of the nestlings was recorded at 20 days of age because the chicks still remained near by the nest; thus, we could determine to which nest they belonged (Hernández-Vázquez and Fernández-Aceves 1999).

A logistic regression model to examine the dependency of nesting success on laying date and clutch type (first versus second and repeat clutches) was used. Logistic regression models have been used to analyze factors affecting nesting success (Staus and Mayer 1999) and are appropriate when response variables are binary (eg. nest success or failure). Analyses were conducted with SPSS for Windows 8.0.

\section{RESULTS}

Clutch size ranged from two to three eggs, but clutches of three eggs were more common in first clutches $(90 \%, \mathrm{~N}=10)$, while clutches of two eggs predominated in second attempts $(73 \%, \mathrm{~N}=15)$. In fact, first clutches were significantly larger ( $\mathrm{t}$-test= $22.9, \mathrm{p}<0.001)$. We lacked information on the clutch size of five nests from the first period because three nests failed before clutch size completion and the other two nests could not be inspected before hatching. Twenty percent of first clutches and $40 \%$ of second attempts failed before hatching.

Eleven 20 day-old nestlings from the seven successful first clutches were counted. Six out of the eight clutches that failed were the last to be laid. In the second period, twelve chicks were fledged from the eight successful clutches. Second attempts presented a similar failure pattern, since five out of the seven failed nests were the last to be laid. In fact, the overall regression model fits the data (Hosmer and Lemeshow Goodness-of Fit statistic $=5.83$, $\mathrm{df}=7, \mathrm{p}=0.56)$ and is significant $\left(\chi^{2}=17.86\right.$, $\mathrm{p}<0.001)$. Within each period, the risk of failure increased significantly as the season progressed $(\mathrm{B}=-0.2, \mathrm{SE}=0.07$, Wald $=8.48, \mathrm{df}=1$, $\mathrm{p}=0.0036$ ). Clutch type variable was excluded from the significance model.

The first nest from the second period had eggs before successful nestlings from the first clutches had fledged, and when failure of the eight first clutches had occurred. 
At the end of each breeding period, offspring remained in a stable group close to the mango trees. The juvenile group of the first clutches had nine individuals, while the juvenile group of the second and repeat clutches had eight individuals. Thus, in relation to the mean clutch size, similar breeding success (20.7\% and $21.7 \%$ respectively) resulted.

Although clutches of three eggs were usual, mainly among first clutches, no pair fledged the three chicks. Since asynchronous hatching as well as great differences in size among individuals within a nest was found, starvation of the youngest chicks in the nest must have been one of the main causes of failure. Nevertheless, no nestling was observed dead in the nest; they may have fallen in the lagoon, been removed by their parents, or predated. However, predation was not observed, although potential predators such as squirrels (Sciurus granatensis), greattailed grackles (Quiscalus mexicanus) and boas (Boa constrictor) were observed in the vicinity of the mango trees. It was also recorded that a chick fell from its nest during an episode of characteristic aggressive behaviour that occurs when adults or chicks come too close to the nests of other individuals. In addition, four nests from the first attempt and five from the second disappeared, coinciding with gusty winds or strong rainstorms.

\section{DISCUSSION}

The mean clutch size in Santa Clara is similar to that reported in Mexico by Juarez (1967), although we did not find clutches of four eggs as they did. In fact, clutches of three eggs must not be scarce in Costa Rica as was pointed out by Stiles and Skutch (1989). Their data may come from nests of the last part of the nesting season, since clutch size reduction is a common pattern in species with several consecutive broods (Morrison 1998, Olmos and Silva 2001), as is the case with the Boat-billed Heron (Juarez 1967) .

The first pair that nested in the second period came from the group that failed in its first attempt. If successful breeders in second attempts were those whose first clutches failed, and could incorporate as early breeders in the second period, at the end of the breeding season most pairs should have raised at least one brood.

The breeding success of the Boat-billed Heron in Santa Clara is higher than that reported in the Mexican mangroves and in protected areas of Costa Rica (Juarez 1967, Carbonell 1993), but coincide with the findings of other studies (Juarez 1967, Hernández-Vázquez and Fernández-Aceves 1999), which show that asynchronous hatching and adverse climatic conditions were the main factors related to nesting death.

Juarez (1967) reported that human activities, such as egg robbery and mangrove pruning, were also important causes of nest failure. Hernández-Vázquez and Fernández-Aceves (1999) did not find reproductive differences between the breeding successes of two colonies of Boat-billed Herons located at different distances from a human settlement. The results of Santa Clara suggest that the conservation of this species is compatible with human presence since they have used this particular site in Santa Clara, Costa Rica for years and that their breeding success is higher there than at other locations studied (Juarez 1967, Carbonell 1993). Therefore, the evidence does not support the view that this species abandons sites that are at a close proximity to human occupancy (Wetmore 1965). Perhaps, the absence of disruptive activities that directly impact reproduction and the presence of some of the characteristics in the area, such as the little patch of forest along the part of the lagoon where herons can roost and take refuge, may have allowed the Boat-billed Herons to the successfully establish in Santa Clara.

\section{ACKNOWLEDGMENTS}

We are grateful to the Sede San Carlos of the Instituto Tecnológico de Costa Rica and the Instituto Clodomiro Picado (UCR) 
for logistical support. Funding was provided by a grant to JG from Agencia Española de Cooperación Internacional, and a Salvador de Madariaga grant to JAGD from the Ministerio de Educación y Ciencia. JSM received a postdoctoral grant from Generalitat Valenciana.

\section{RESUMEN}

Estudiamos el éxito reproductivo de una colonia del ave Cochlearius cochlearius en una zona ganadera de Costa Rica. El promedio de huevos por nido fue mayor durante el periodo de primeras puestas (2.9 huevos/nido) que durante el periodo de segundas puestas y reposiciones (2.3 huevos/nido). El éxito reproductor de los dos periodos fue similar (20.7\% y $21.7 \%$, respectivamente). En ambos tuvieron más éxito las parejas que comenzaron la puesta antes. Las principales causas de mortandad fueron inanición de los pollos más jóvenes del nido y la destrucción de los nidos debido a condiciones climáticas adversas. No notamos efectos adversos por la actividad humana.

Palabras clave: Chocuaco pico cuchara, Cochlearius cochlearius, depredación, inanición, molestias humanas, tamaño de puesta.

\section{REFERENCES}

Carbonell, M. 1993. Éxito reproductor del Chocuaco Pico Cuchara, Cochlearius cochlearius, en el Río Tempisque, Costa Rica. In Resúmenes del I Congreso de Ornitología de Costa Rica. San José, Costa Rica. 25 p.
Dickerman, R.W. \& L.C. Juárez. 1971. Nesting studies of the boat-billed heron Cochlearius cochlearius at San Blas, Nayarit, Mexico. Ardea 59: 1-16.

Gómez, J., J.A. Gil-Delgado \& J.S. Monrós. 2001. Doublebrooding in the Boat-billed Heron. Waterbirds 24: 282-284.

Hancock, J. \& J. Kushlan. 1984. The Herons Handbook. Croom Helm, London, England. 288 p.

Hernández-Vázquez, S. \& G.J. Fernández-Aceves. 1999. Reproducción de Cochlearius cochlearius (garza cucharón) y Butorides virescens (garza verde) en la Manzanilla, Jalisco, México. Cienc. Mar. 25: $277-$ 291.

Juarez, L.C. 1967. Observaciones acerca de la biología, nidificación y crianza de la garza pico de cucharón mexicana, Cochlearius cochlearius, en San Blas, Nayarit. Tesis de Licenciatura, Universidad Autónoma de México, México, DF, Mexico. 100 p.

Morrison, J.L. 1998. Effects of double brooding on productivity of Crested Caracaras. Auk 115: 979-987.

Olmos, F. \& R. Silva. 2001. Breeding biology and nest site characteristics of the Scarlet Ibis in Southeastern Brazil. Watebirds 24: 58-67.

Staus, N.L. \& P.M. Mayer. 1999. Arthropods and predation of artificial nests in the Bahamas: implications for subtropical avifauna. Wilson Bull. 111: 561-564.

Stiles, F.G. \& A.F. Skutch. 1989. A Guide to the Birds of Costa Rica. Cornell, New York, USA. 511 p.

Wetmore, A. 1965. The birds of the Republic of Panama. I. Tinamidae (Tinamous) to the Rhynchopidae (Skimmers). Smiths. Misc. Coll. 150: 1-483. 